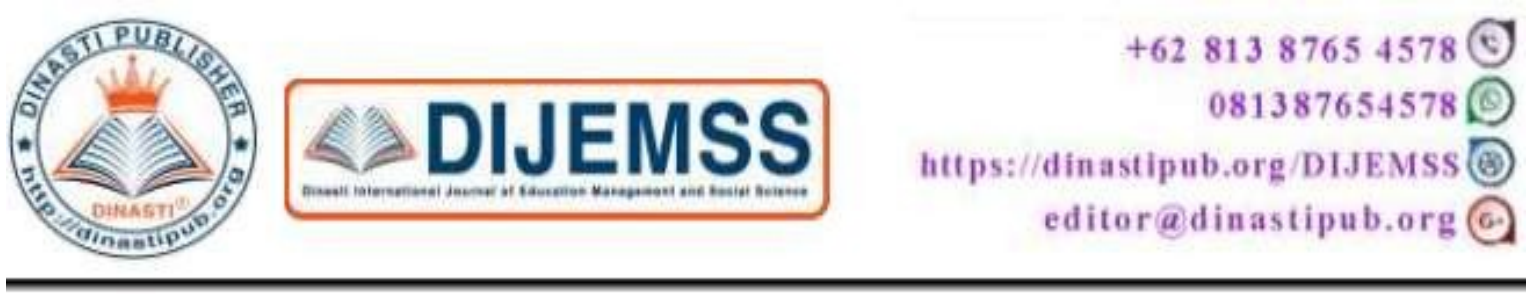

\title{
ANALYSIS OF FACTORS INFLUENCING THE ACCOUNTABILITY OF VILLAGE FUNDS MANAGEMENT
}

\section{R. Budi Hendaris ${ }^{1}$, Rahmat Siraz ${ }^{2}$}

1) Jenderal Ahmad Yani, University, Cimahi, Indonesia

2) Jenderal Ahmad Yani, University, Cimahi, Indonesia

\begin{tabular}{|l|l|}
\hline ARTICLE INFORMATION & $\begin{array}{l}\text { Abstract: To achieve a good village fund } \\
\text { Received: 1 February 2020 } \\
\text { mevised: } 7 \text { February 2020 } \\
\text { Issued: 11 February 2020 } \\
\text { fund. Accountability is needed to explain the } \\
\text { management of village funds. As a form of } \\
\text { responsibility for the management of this fund, } \\
\text { created the financial statements of the village. This } \\
\text { R. Budi Hendaris }\end{array}$ \\
$\begin{array}{l}\text { E-mail: } \\
\text { budi.hendaris@lecture.unjani.ac.id aimed to analyze whether the competence of } \\
\text { human resources, the implementation of village } \\
\text { financial system, and the implementation of internal } \\
\text { control systems of government affect the } \\
\text { accountability of village funds management . This } \\
\text { research is descriptive and causal using survey by } \\
\text { distributing questionnaires to the respondents who } \\
\text { have been determined. The respondents totaled 160 } \\
\text { respondents who are fund managers villages in West } \\
\text { Bandung regency. For data analysis, this study uses } \\
\text { PLS SEM assisted by Smart PLS software program } \\
\text { version 3.0. } \\
\text { Keywords: Accountability, Competence, Village }\end{array}$ \\
DOI:10.31933/DIJEMSS & \begin{tabular}{l} 
Financial System, the Internal Control System \\
\hline
\end{tabular}
\end{tabular}

\section{INTRODUCTION}

The Central Government of Indonesia in the last few years being actively develop the village as the main focus of development. One of the efforts to increase development in rural sector, namely by giving the village fund program, directly from the central budget to be managed independently by village communities to promote the development and standard of living in rural areas.

The Central Government has spent the village since 2015 up to now with the huge amount that has been distributed to all villages in Indonesia. In 2015 has distributed Rp 20.7 trillion, 2016 amounting to Rp 46.98 trillion, the Year of 2017 amounted to 60 trillion in 2018 amounted to 60 trillion. The village government has used the village funds to carry out 
development in the region, such as for construction of facilities and infrastructure. So it has a lot of infrastructure that has been built, in order to improve the welfare of rural communities.

As a result of the distribution of funds is so great village to every village, it cause several village heads who do corruption. Based on data from ICW, many village heads who undergo the legal process because of corruption. In the period from 2015 until 2018 there were 212 village heads who do corruption. This indicates that there is financial mismanagement village funds. The funds should be used for the welfare of rural communities apparatus used for personal use village.

To anticipate the mismanagement of funds of the village, the village government should undertake a process of accountability. According Hasniati (2016) accountability that can be applied in the village administration is bureaucratic accountability. Bureaucratic accountability is the process of what has been implemented by the government officials to stakeholders. From planning to reporting management of village funds must be accounted for.

Based on the phenomenon already described, the objective of this study is to look at the influence of factors which will affect the village fund management accountability. These factors include the competence of human resources, the implementation of village financial system and the implementation of the internal control system of government implemented in West Bandung regency government.

\section{LITERATURE REVIEW}

\section{Village Fund Management Accountability}

Accountability suitable for the village fund management accountability is known as bureaucratic accountability (Hasniati,2016). Bureaucratic accountability in implementing programs for the public interest is an obligation that can not be negotiable. It is given to the public as the target group of a program is always demanding transparency and accountability in the budget process (Carlitz in Hasniati,2016).

Implementation of accountability by the organization or government agency is influenced by factors that can support or inhibit, among other things: 1) Factors awareness of officers / employees, 2) Factors rules, 3) Factors organization, 4) Factors abilities and skills, and 5) factors facilities (Moenir in Muradi and Rusdi, 2013: 194-196).

The principle of accountability of the bureaucracy is weheter the services provide have met the criteria determined by the stakeholders. Method or a way to measure the accountability of the bureaucracy can be seen from the five (5) principles of accountability, transparency, liability, controllability, responsibility, and responsiveness (UNDP in Hasniati,2016). The principle of transparency related to whether the organization concerned is able to express facts about its performance. Principle responsibilities with regard to whether the organization concerned face the consequences of its performance. Controllability principle related to whether the organization concerned to do what is desired by the party giving the assignment. The principle of liability associated with whether the organization concerned has the responsibility of existing performance standards. The principle of responsiveness is whether the organization in question fulfill real expectations of stakeholders.

\section{The Relations Between Human Resources Competency and the Village Fund Management Accountability}

Human resource is human capital within the organization. Human capital is the 
knowledge, skills, and ability that can be used to produce professional services and the economic rent. Human capital is a source of innovation and ideas. Employees who with high human capital are more likely to provide consistent service and high quality (Arsyiati, 2010).

Competence of human resources (HR) is the ability of HR to perform the duties and responsibilities assigned to him by the provision of education, training and experience are sufficient. Competent human resources will be able to understand the logic of accounting properly. The ability of an individual or individuals in an organization can be seen from the achievement of the goals and the effectiveness and efficiency of performance resulting in outputs and outcomes (Zuliarti, 2012). If the capabilities of financial management staff is good, then the output or result in the financial statements, the better. The failure of the local government human resources in understanding and applying the accounting logic would have an impact on the financial statements that were made in error and discrepancy reports with the standards set by the government (Warisno, 2010). HR competencies include the capacity, the ability of a person or an individual, an organization, or a system to carry out its functions or powers to achieve its objectives effectively and efficiently. Capacity should be seen as the ability to achieve the performance, to produce the outputs and outcomes. (Roviyantie, 2011).

Competence is the knowledge and expertise necessary to complete the task. Competence of adequate human resources in terms of quantity and quality will improve accountability in local government financial reporting. This is consistent with research Sapto et al (2016), Ekasari \& Ivan (2017), Arif at al (2017), Suherwan \& Komariah (2017), Riadul Jannah et al (2018), Haryono Umar (2018), Yaya \& Santosa (2018), Nur Ida (2018), Dharma (2018), Budiana et al (2019), Ni Komang Ayu et al (2019), Research results show that there is a positive relationship between the competence of human resources with the performance of the financial management of the village. Based on these descriptions, then the hypothesis as follows:

\section{H1: Human resources competency has positive effect on the accountability of village fund management.}

\section{The Relationship Village Financial System Implementation (Siskeudes) and the Accountability of Village Fund Management}

Village Financial System (Siskeudes) is a system created by the Financial and Development Supervisory Agency (BPKP) to assist the Government's financial management of the village. Application of Village Financial System $t$ program conducted by using information technology to support the Regional Financial Information System. Village financial system used to document, administer, and process data management of village finances or other related data into a useful information for the public that will be the basis for decision making in planning, execution, and reporting of the village government accountability. Indicators used to measure Application of village financial system is planning, village financial budgeting, village financial implementation, the financial administration of the village, reporting and accountability, financial oversight village. Thus, if a country has implemented village financial system government can help improve the accountability of the fund management of the village. This is consistent with the results of research by Zuliarti (2012), Ni Putu Chandra (2016), Ekasari \& Ivan (2017), Riadul Jannah (2018), Yaya \& Santoso (2018) that the use of information technology affects the village fund management accountability. Based on these descriptions can be made hypotheses:

\section{H2: Village Financial System Implementation positive effect on the Accountability Village management Fund}




\section{The Relationship Government Internal Control System Implementation and The Accountability of Village Fund Management}

In the case of the introduction of a system of Government Internal pengendalikan (SPIP) has created a guideline that starts from PP 60 of 2008 which is more like the following. Based on the regulation SPIP applied to achieve organizational goals through a process integral to the actions and activities by the leaders and all employees continuously to provide reasonable assurance that carried through activities of effective and efficient financial reporting presented reliably, safeguards against state assets and comply with the legislation in force. Based on the Indonesian Government Regulation No. 60 of 2008 that internal control is a process that is influenced by human resources and information technology systems designed to assist an organization in achieving certain goals.

Internal control is a way to direct, monitor, and measure an organization's resources, as well as having a very important role in the prevention and detection of fraud (fraud). Indicators used to measure the implementation of the Government Internal Control System are: control environment, risk assessment, control activities, information and communication, monitoring. (PP No. 60 of 2008). Results of research conducted by Zuliarti (2012), Arif \& Lola (2017), Haryono Umar (2018), Yaya \& Santosa (2018), Nur Ida (2018), Budiana et al (2019), Utamingtyas (2019) that the government internal control system positively affects the accountability of village fund management accountability. Based on these descriptions can be made the following hypotheses:

H3: Implementation of Government Internal Control Systems positive effect on the Accountability of Village Fund Management

\section{RESEARCH METHODS}

The research method used the explanatory research. The unit of analysis in this study is 160 village in West Bandung Regency. Respondents is the village treasurer. This Research was carried out in 2019. This research is descriptive and causal using survey by distributing questionnaires to the respondents. For data analysis, this study uses PLS SEM assisted by Smart PLS software program version 3.0.

\section{FINDINGS AND DISCUSSION}

\section{Human Resources Competency, Implementation of Village Financial System,} Implementation of Government Internal Control Systems on the accountability management of the Village.

\section{Measurement Model}

Measurement using Partial Least Square estimation method, obtained full path diagram models, influence human resources competence, village financial system implementation, government internal control systems implementation on the accountability of village fund management. 


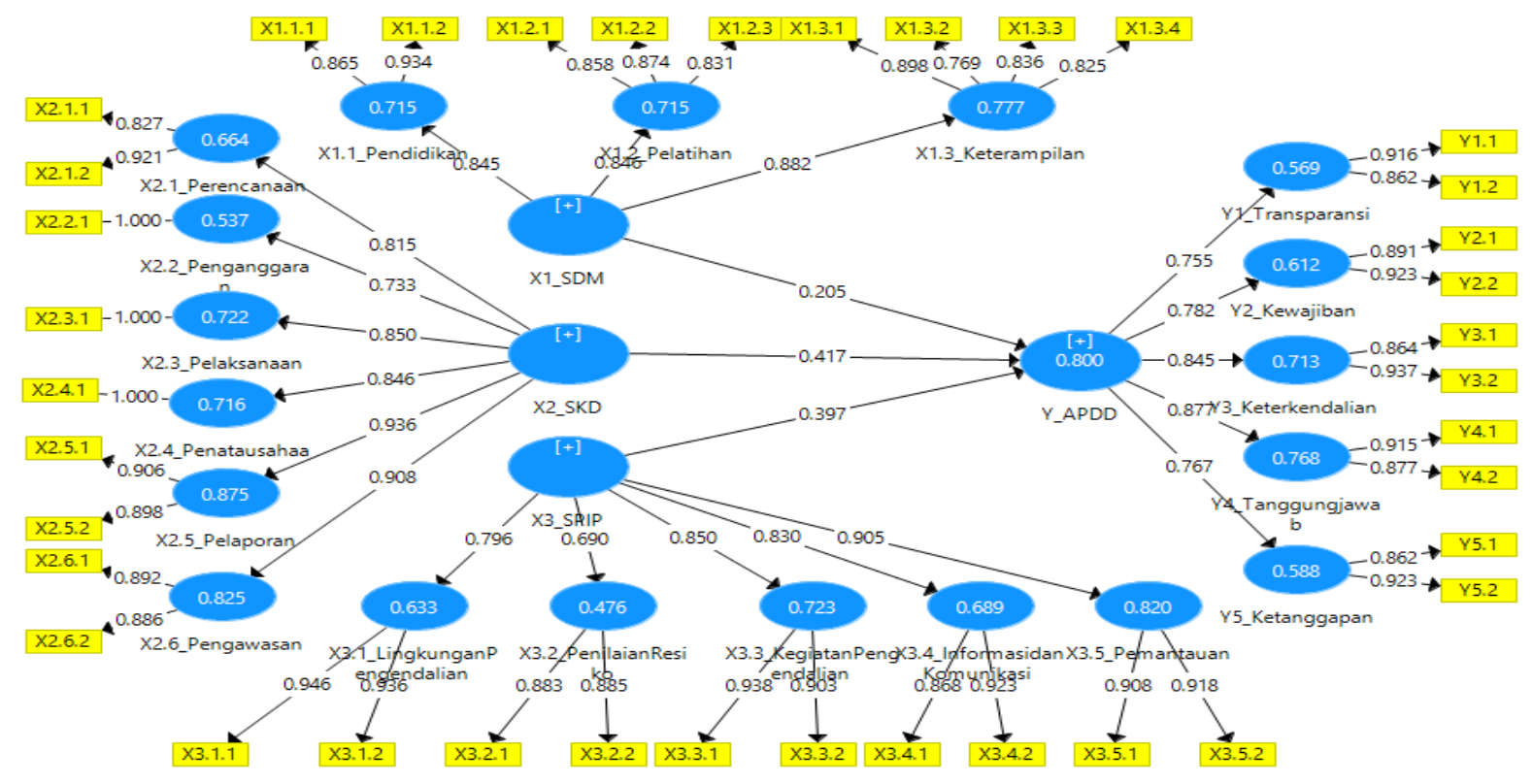

Figure 1 Coefficient Standar Structural Modeling

The calculations show that the influence of human resources competence on the accountability of village fund Management indicated by the path coefficient of 0.205 , the effect financial system village implementation on accountability of village fund management indicated by the path coefficient of 0.417 , and the effect governement internal control system on accountability of village fund management is indicated by the path coefficient value of 0.397 .

Structural equation model for human resource competency influence, Implementation of Village Financial System, Government Internal Control Systems on Accoutability of Village Fund management is as follows:

$$
\eta=0.205 \xi_{1}+0.417 \xi_{2}+0.397 \xi_{3}+0.200
$$

\section{Testing Measurement Model (outer model) \\ Result of Convergent Validity Test}

Table 1 Weighting factor variabel of human resources competence

\begin{tabular}{|c|c|c|c|c|c|c|}
\hline \multirow[b]{2}{*}{ Dimension } & \multicolumn{2}{|c|}{ Loading Indicator } & \multirow[b]{2}{*}{$\mathrm{E}$} & \multirow[b]{2}{*}{ Measurement Model } & \multirow[b]{2}{*}{$\mathrm{T}_{\text {count }}$} & \multirow[b]{2}{*}{$\begin{array}{c}\mathrm{P} \\
\text { value }\end{array}$} \\
\hline & $\begin{array}{c}\text { Factor } \\
(\lambda)\end{array}$ & $\begin{array}{c}\text { Reliability } \\
\left(\lambda^{2}\right)\end{array}$ & & & & \\
\hline $\begin{array}{c}\text { Educational } \\
\text { Background } \\
\left(\mathrm{X}_{11}\right)\end{array}$ & 0,845 & 0,715 & 0,285 & $\begin{array}{c}\mathrm{X} 11=0,845 \mathrm{X} 1+ \\
0,285\end{array}$ & 42,484 & 0,000 \\
\hline Training $\left(\mathrm{X}_{12}\right)$ & 0,846 & 0,715 & 0,285 & $\begin{array}{c}\mathrm{X} 12=0,846 \mathrm{X} 1+ \\
0,285\end{array}$ & 37,298 & 0,000 \\
\hline $\begin{array}{l}\text { Skill Carrying } \\
\text { out tasks }\left(\mathrm{X}_{13}\right)\end{array}$ & 0,882 & 0,777 & 0,223 & $\begin{array}{c}\mathrm{X} 13=0,882 \mathrm{X} 1+ \\
0,223\end{array}$ & 41,791 & 0,000 \\
\hline
\end{tabular}

Source: Primary data

Based on the results in Table 1, Results of the calculations for the three-dimensional loading factor of latent variables competence of human resources (X1) ranged from 0.8 to 0.9 . Results of outer value calculation model or construct correlation between the variables (loading factor) meet convergent validity with loading factor of greater than 0.7 . Values above 0.7 so 
that the loading factor constructs (manifest variables) for Human Resources competency (X1) nothing is eliminated from the model.

T-count obtained for each loading factor for 3-dimensional latent variable competence Human Resources competence (X1) is more than 1.96, so it can be said that the manifest variables used in measuring the variables meaningful Human Resources competency (X1).

Based on calculations loading factor and the t-statistic is known that there are three dimensions of the Human Resource Competency has positive and significant relationship in determining Human Resourcescompetency.

Results Indicator Reliability $\left(\lambda^{2}\right)$ at table 1 more than 0.5 indicates that the variable dimension Human Resources competency (X1) already meet Convergent Validity.

Table 2 Weighting factor variabel Implementation of Village Financial System

\begin{tabular}{|c|c|c|c|c|c|c|}
\hline \multirow[b]{2}{*}{ Dimension } & \multicolumn{2}{|c|}{ Loading Indicator } & \multirow[b]{2}{*}{$\mathbf{E}$} & \multirow[b]{2}{*}{$\begin{array}{l}\text { Measurement } \\
\text { Model }\end{array}$} & \multirow{2}{*}{\multicolumn{2}{|c|}{$\mathbf{T}_{\text {count }}$}} \\
\hline & $\begin{array}{c}\text { Factor } \\
(\lambda)\end{array}$ & $\begin{array}{c}\text { Reliability } \\
\qquad\left(\lambda^{2}\right)\end{array}$ & & & & \\
\hline $\begin{array}{l}\text { Development } \\
\text { Planning }\left(\mathrm{X}_{21}\right)\end{array}$ & 0,815 & 0,664 & 0,336 & $\begin{array}{c}\mathrm{X}_{21}=0,815 \mathrm{X}_{2}+ \\
0,336\end{array}$ & 28,750 & 0,000 \\
\hline $\begin{array}{l}\text { Village Financial } \\
\text { Budgeting }\left(\mathrm{X}_{22}\right)\end{array}$ & 0,733 & 0,537 & 0,463 & $\begin{array}{c}\mathrm{X}_{22}=0,733 \mathrm{X}_{2}+ \\
0,537\end{array}$ & 18,076 & 0,000 \\
\hline $\begin{array}{c}\text { Village Financial } \\
\text { Implementation } \\
\left(\mathrm{X}_{23}\right)\end{array}$ & 0,850 & 0,722 & 0,278 & $\begin{array}{c}\mathrm{X}_{23}=0,850 \mathrm{X}_{2}+ \\
0,278\end{array}$ & 31,476 & 0,000 \\
\hline $\begin{array}{c}\text { Village Financial } \\
\text { Administration }\left(\mathrm{X}_{24}\right)\end{array}$ & 0,846 & 0,716 & 0,284 & $\begin{array}{c}\mathrm{X}_{24}=0,846 \mathrm{X}_{2}+ \\
0,716\end{array}$ & 42,354 & 0,000 \\
\hline $\begin{array}{c}\text { Reporting \& } \\
\text { Accountability } \\
\text { (X25) }\end{array}$ & 0,936 & 0,875 & 0,125 & $\begin{array}{c}\mathrm{X} 25=0,936 \mathrm{X} 2+ \\
0,125\end{array}$ & 68,780 & 0,000 \\
\hline Supervision (X26) & 0,908 & 0,825 & 0,175 & $\begin{array}{c}\mathrm{X} 26=0,908 \mathrm{X} 2+ \\
0,17\end{array}$ & 67,152 & 0,000 \\
\hline
\end{tabular}

Source: Primary data

Based on the results in Table 2, Loading factor calculation results for the six dimensions of latent variables implementation of village financial system (X2) ranged from 0.7 to 0.9 . Results of outer value calculation model or construct correlation between the variables (loading factor) met Convergent Validity with loading factor of greater than 0.7 . Values above 0.7 so that the loading factor constructs (manifest variables) for village Financial System implementation (X2) nothing is eliminated from the model.

T-count obtained for each loding factor for the 6 dimensions of latent variables village Financial System implementation (X2) is more than 1.96, so it can be said that the manifest variables used in measuring the variables meaningful village Financial System implementation (X2).

Based on calculations loading factor and the t-statistic is known that there are six dimensions implementation of villagel Financial System which has a positive and significant relationship in determining village financial system implementation.

Results indicator reliability $\left(\lambda^{2}\right)$ In the table 3 is more than 0.5 indicates that the variable dimension implentation of village financial system implementation (X2) meet convergent validity. 
Table 3 Weighting factor variabel implantation of Internal Control System Government

\begin{tabular}{|c|c|c|c|c|c|c|}
\hline Dimension & $\begin{array}{c}\text { Loading } \\
\text { Factor } \\
(\lambda)\end{array}$ & $\begin{array}{l}\text { Indicator } \\
\text { Reliability } \\
\qquad\left(\lambda^{2}\right)\end{array}$ & $\mathrm{e}$ & Measurement Model & t-count & $\begin{array}{c}\mathrm{P} \\
\text { value }\end{array}$ \\
\hline $\begin{array}{l}\text { Control Environment } \\
\left(\mathrm{X}_{31}\right)\end{array}$ & 0,796 & 0,633 & 0,367 & $X_{31}=0,796 X_{3}+0,367$ & 23,708 & 0,000 \\
\hline Risk Assessment (X32) & 0,690 & 0176 & 0,524 & $X_{32}=0,690 X 3+0,524$ & 15,665 & 0,000 \\
\hline $\begin{array}{c}\text { Control Activities } \\
\text { (X33) }\end{array}$ & 0,850 & 0,723 & 0,277 & $X_{33}=0,850 X 3+0,277$ & 34,564 & 0,000 \\
\hline $\begin{array}{c}\text { Information \& } \\
\text { Communication (X34) }\end{array}$ & 0,830 & 0,689 & 0,311 & $\mathrm{X}_{34}=0,830 \mathrm{X} 3+0,311$ & 31,458 & 0,000 \\
\hline Monitoring (X35) & 0,905 & 0,820 & 0,180 & $X_{35}=0,905 X 3+0,180$ & 86,627 & 0,000 \\
\hline
\end{tabular}

Source: Primary data

Based on the results in Table 3, The results of calculations for the loading factor of 5 dimensions of latent variables Government internal control system implementation (X3) ranged from 0.8 to 0.9 . Results of outer value calculation model or construct correlation between the variables (loading factor) meet convergent validity with loading factor of greater than 0.7 . Values above 0.7 so that the loading factor constructs (manifest variables) for the Implementation of government internal control system (X3) are not eliminated from the model.

T-count obtained for each loding factor for the 6 dimensions of latent variables government control system implementation (X3) is more than 1.96, so it can be said that the manifest variables used in measuring the variables meaningful government control system implementation (X3).

Based on calculations loading factor and the t-statistic is known that there are six dimensions of Implementation of government internal control system has positive and significant relationship in determining the application of Government internal control system.

Results Indicator Reliability $\left(\lambda^{2}\right)$ In the at table 4 is more than 0.5 indicates that the application of variable dimension government internal control system (X3) meet convergent validity.

Table 4 Weighting factor variable Accountability of Village Fund Management Loading Indicator

\begin{tabular}{cccccccc}
\hline Dimensi & $\begin{array}{c}\text { Loading Indicator } \\
\text { Factor } \\
(\lambda)\end{array}$ & $\begin{array}{c}\text { Reliability } \\
\left(\lambda^{2}\right)\end{array}$ & $\mathrm{E}$ & Measurement Model & $\mathrm{t}_{\text {-count }}$ & $\begin{array}{c}\mathrm{P} \\
\text { value }\end{array}$ \\
\hline Transparancy $\left(\mathrm{Y}_{1}\right)$ & 0,755 & 0,569 & 0,431 & $\mathrm{Y}_{1}=0,755 \mathrm{Y}+0,431$ & 16,902 & 0,000 \\
\hline Liability $\left(\mathrm{Y}_{2}\right)$ & 0,782 & 0,612 & 0,388 & $\mathrm{Y}_{2}=0,782 \mathrm{Y}+0,388$ & 24,420 & 0,000 \\
\hline Controllability $\left(\mathrm{Y}_{3}\right)$ & 0,845 & 0,713 & 0,287 & $\mathrm{Y}_{3}=0,845 \mathrm{Y}+0,287$ & 47,674 & 0,000 \\
\hline Responsibility $\left(\mathrm{Y}_{4}\right)$ & 0,877 & 0,768 & 0,232 & $\mathrm{Y}_{4}=0,877 \mathrm{Y}+0,232$ & 55,156 & 0,000 \\
\hline $\begin{array}{c}\text { Responsiveness } \\
\left(\mathrm{Y}_{5}\right)\end{array}$ & 0,767 & 0,588 & 0,412 & $\mathrm{Y}_{5}=0,767 \mathrm{Y}+0,412$ & 15,646 & 0,000 \\
\hline
\end{tabular}

Source: Primary data

Based on the results in Table 4, T-count obtained for each loding factor for 5dimensional calculation results loading factor for the 5 dimensions of latent variables accountability of village fund management $(\mathrm{Y})$ ranges from 0.7 to 0.9 . Results of outer value calculation model or construct correlation between the variables (loading factor) meet convergent validity with loading factor of greater than 0.7 . Values above 0.7 so that the loading 
factor constructs (manifest variables) for accountability of village fund management accountability (Y) nothing is eliminated from the model.

from latent variable accountability of village fund management $(\mathrm{Y})$ is more than 1.96 , so it can be said that the manifest variables used in measuring meaningful village fund management.

Based on calculations loading factor and the t-statistic is known that there are six dimensions of accountability of Village Fund Management Accountability have positive and significant relationship in determining accountability of Village Fund Management.

Results Indicator Reliability $\left(\lambda^{2}\right)$ In the table 5 is more than 0.5 indicates that the dimensions of accountability of village fund management $(Y)$ meet convergent validity.

\section{Result of Discriminat Validity Test}

Table 5 : Result of Dsicriminat Validity Test

\begin{tabular}{crrrc}
\hline & X1_HRC & X2_VFS & X3_GICS & Y_AVFM \\
\hline X1_HRC & 0.734 & & & \\
\hline X2_VFS & 0.604 & 0.796 & & \\
\hline X3_GICS & 0.661 & 0.650 & 0.744 & \\
\hline Y_AVFM & 0.719 & 0.799 & 0.804 & 0.721 \\
\hline
\end{tabular}

Source: Primary data

Based on the results in Table 5, The correlation between the constructs and roots AVE shows that the root of AVE for each variable is greater than the value of the correlation between variables constructs his or her research. In general, these results indicate that the latent variable discriminant validity were already high. This shows that all constructs have a good consistency.

\section{Result of Reliability Test}

Table 6. Result of Reliability Test

\begin{tabular}{cccl}
\hline Variable & Crobach's Alpha & $\begin{array}{l}\text { Composite } \\
\text { Reliability }\end{array}$ & Remark \\
\hline HRC & 0.890 & 0.912 & Reliable \\
\hline VFS & 0.917 & 0.939 & Reliable \\
\hline GICS & 0.905 & 0.939 & Reliable \\
\hline AVFM & 0.891 & 0.914 & Reliable \\
\hline
\end{tabular}

Source: Primary data that have been processed through SmartPLS 3.8

Based on the results in Table 6, it can be seen that all values of crombach's alpha and composite reliability are greater than 0.7 . Thus, it can be conclude that all measurement used in this study reliable.

\section{Testing Measurement Inner Model}

Inner Models describe the relationship between latent variables based on substantive theory of structural models in evaluation using R-Square $\left(\mathrm{R}^{2}\right)$ for endogenus constructs. Chin (1998) in Ghozali and Latan (2015) state that the R-Square result describe in endogoneus variables shoud be above 0.33 so it can be stated the endogenous construct are moderate. Here is R-Square value generated in this study: 
Table 7. R-Square Value

Accountablity of Village Fund Management

\section{R-Square}

Source: Primary data that have been processed through SmartPLS 3.8

Based on the results in Table 7, shows the R-square value for accountability of village fund management accountability variable $(\mathrm{Y})$ obtained at 0,800 . These results indicate that $80.0 \%$ of accountability of village fund management variables are influenced by variables human resources competency, village financial system implementaion and government internal control systems.

\section{Rate $\mathbf{2} 2$ effect size structural model}

Effect size $\mathrm{f} 2$ shows the contribution of each construct to accountability of village fund management accountability, $\mathrm{f} 2$ value equal to $0: 02,0: 15,0: 35$ can be interpreted that the predictor variables have an influence latent small, medium and large (Hair, 2017). The calculation results Effect size $\mathrm{f} 2$ are given in Table 8.

Tabel 8 Size-effect assessment Structural Model

\begin{tabular}{|c|c|c|}
\hline endogenous construct & $\begin{array}{l}\text { Effect } \\
\text { size f2 }\end{array}$ & Information \\
\hline Human Resources Competency (X1) & 0.107 & small influence \\
\hline Village Financial System (X2) & 0,455 & large influence \\
\hline Government Internal Control System (X3) & 0.366 & large influence \\
\hline
\end{tabular}

Source: Primary data

Score eeffect size f2 human resources competency (X1) obtained by 0.107 in the category of small effect size, $\mathrm{f} 2$ village Financial System (X2) obtained by 0,455 in the category of large and effect size f2 government internal control systems (X3) obtained at .366 in the category large.

\section{Hypothesis Testing Results}

Table 9 Test Results of significance of Influence

\begin{tabular}{ccccccc}
\hline & $\begin{array}{c}\text { Original } \\
\text { Sample (O) }\end{array}$ & $\begin{array}{c}\text { Sample } \\
\text { Mean } \\
(\mathbf{M})\end{array}$ & $\begin{array}{c}\text { Standard } \\
\text { Deviation } \\
(\text { STDEV) }\end{array}$ & $\begin{array}{c}\text { T Statistics } \\
(\mid \mathbf{O} / \text { STDEV })\end{array}$ & P Values & $\begin{array}{c}\text { Efek } \\
\text { size f } \boldsymbol{f}^{2}\end{array}$ \\
\hline $\begin{array}{c}\text { X1_SDM -> } \\
\text { Y_APDD }\end{array}$ & 0,205 & 0,196 & 0,045 & 4,579 & $\mathbf{0 , 0 0 0}$ & 0,107 \\
\hline $\begin{array}{c}\text { X2_SKD -> } \\
\text { Y_APDD }\end{array}$ & 0,417 & 0,417 & 0,072 & 5,787 & $\mathbf{0 , 0 0 0}$ & 0,455 \\
\hline $\begin{array}{c}\text { X3_SPIP - } \\
\text { Y_APDD }\end{array}$ & 0,397 & 0,402 & 0,077 & 5,147 & $\mathbf{0 , 0 0 0}$ & 0,366 \\
\hline
\end{tabular}

Source: Primary data

Based on the results in Table 7, it can be seen that the first hypothesis is accepted. This indicated by the t-statistic $4.579>1.960$ (t-tabel), meaning that human resources competence have signifikan postitive effect on the accountability of village funds management. Similar to the first hypothesis, The second hypothesis is accepted because the value of t-statistic 5.787 $>1.960$ 
means that the implementation of village financial system has a significant positive effect on the accountability of village funds management. Likewise, the third hypothesis is accepted because the value of t-statistic $5.147>1.960$ means that the implementation of internal control system government has a significant positive effect on the accountability of village funds management.

\section{DISCUSSION}

\section{Effect of Human Resources Competence on Accountability of Village Funds Management}

The Result of this study found that human resources competence have signifikan positive effect on accountability of village funds management. This means that the better the human resources competence, the better level of accountability of village fund management.

The result of this study support previus studies by Sapto et al (2016), Ekasari \& Ivan (2017), Arif at al (2017), Suherwan \& Komariah (2017), Riadul Jannah et al (2018), Haryono Umar (2018), Yaya \& Santosa (2018), Nur Ida (2018), Dharma (2018), Budiana et al (2019), Ni Komang Ayu et al (2019).

\section{Effect of Village Financial System implementation on Accountability of Village Funds Management}

The results of this study found that village financial system implementation has significant positive effect on accountability of village funds management. This means that use of village financial system can help accountability of village funds. The result of this study support previous research as conducted by Zuliarti (2012), Ni Putu Chandra (2016), Ekasari \& Ivan (2017), Riadul Jannah (2018), Yaya \& Santoso (2018).

\section{Effect of Government Internal Control implementation on Accountability of Village Funds Management}

The results of this study found that internal control government implantation has significant positive effect on accountability of village funds management. This means that use government internal control system can help accountability of village funds management. The results of this study support previous research as conducted by Zuliarti (2012), Arif \& Lola (2017), Haryono Umar (2018), Yaya \& Santosa (2018), Nur Ida (2018), Budiana et al (2019), Utamingtyas (2019).

\section{CONCLUSION AND SUGESTION CONCLUSION}

Based on the results of data analysis has been done, it can be concluded that human resources competency, village financial system implementation, government internal control system have signifikan postitive effect on the accountability of village funds management. human resources competency category of small effect size, village financial system and government internal control systems category of large effect size.

Implications of these results that the implementation of accountability of funds management in local government funds will be successful if considering the competence of human resources, improving infrastructure for village financial system and carry out the internal control of the government. 


\section{SUGESTION}

It is recommended for local government to strengthen the aparatur competence with the education training implementation of Village Financial System. For the next researcher need to develop this research as commitment organizational, moral, motivation and so forth.

\section{REFERENCE}

Arif dan Diarespati, Lola.2017. Pengaruh Kompetensi dan Sistem Pengendalian Intern Terhadap Akuntabilitas Pemerintah Desa Dalam Mengelola Alokasi Dana Desa. Jurnal Berkala Akuntansi dan Keuangan Indonesia, Vol 2, No 02 Tahun 2017:1-20

Ayu, NK. Gayatri, Julia. (2019). Faktor Faktor yang Berpengaruh Pada Akuntabilitas Pengelolaan Dana desa Study Pada Kecamatan Abang Kabupaten Karang Asem. E Jurnal Akuntansi Universitas Udayana. Volume 26.2 Feb: 1269 - 1298.

Budiana et al.2019.The Effect of Village Device Competencies And Internal Control System On Accountability of Village Management. Scientific Research journal (SCIRJ). Volume VII,Issue 1 Januari 2019. ISSN -2201-2796

Carlitz, Ruth.(2013). Improving Transparancy and Accountability in the Budget Process: An Assessment of Recent. Initiatives Development Policy Review. Volume 31, pg 549-567.

Ghozali, Imam. Latan.2015. "Structural Equation Modeling, Metode Alternatif Dengan Partial Least Squares (PLS) ”. Semarang: Universitas Diponegoro

Hair, Joseph. F., Hult, G. T. M., Ringle, Christian. M., Sarstedt, Marko.2017. A Primer on Partial Least Squares Strucutural Equation Modeling (PLS-SEM), $2^{\text {nd }}$ edition. California: SAGE Publication, Inc.

Hasniati.2016.Model Akuntabilitas Pengelolaan Dana Desa. Jurnal Analisis dan Pelayanan Publik. Volume 2 No 1 Juni 2016. P.ISSN:2460-6162, E ISSN:2527-6476.

Hendri, Sapto. et al.(2016). Pengaruh Sumber Daya Manusia, Sarana dan Prasarana Terhadap Kinerja Pengelolaan Keuangan desa di Kabupaten Lombok Tengah. Conference on Management and Behavioral Studies University Tarumanegara Jakarta, 27 Okt 2016. E ISSN No: $2541-2850$.

Jannah, Riadul.et al.2018.The Influence of Human Resources, Use of Information Technology and Public Participation to The Transparancy and Accountability of Village Financial Management.International Journal of Scientific Research and Management (IJSRM) Volume 06, Issue 05, pp. EM-2018-373-385.Index Covernicus Value (2015):57,47, (2016):93:67, DOI:10:18535/ijsrm/v615.em 03

Muradi.Rusli.2013.Akuntabilitas Pelayanan Publik. Jurnal Adminsitrasi Pembangunan. Volume 1 No:2, Hal 101-218.

Roviyantie,D.2011.Pengaruh Kompetensi Sumber Daya Manusia dan Penerapan Sistem Akuntansi Keuangan Daerah Terhadap Kualitas Laporan Keuangan Daerah. Universitas Siliwangi

Sugiarti, ES. Yudianto,Ivan.2017. Analisis Faktor Kompetensi Sumber Daya Manusia, Pemanfaatan Teknologi Informasi dan Partisipasi Penganggaran Terhadap Akuntabilitas Pelaporan dana Desa. Proceding Seminar Nasional Akuntansi \& Bisnis Universitas Widyatama. ISSN : 2252 - 3936.

Suherwan. Komaliah.(2017). Analisis Faktor -Faktor Yang Mempengaruhi Keberhasilan Implementasi Alokasi Dana Desa. (Studi Kasus di Kecamatan Siantar Selatan Kabupaten Kepulauan Anambas). Jurnal Tepak Manajemen Bisnis Vol IX No 2 Mei 2017.

Sugiono.2014. Metode Penelitian, Kuantitatif, Kualitatif dan R\&D. Penerbit Apha Beta, Jakarta. 
Umar, Husen.2010. Metode Penelitian untuk Skripsi dan Tesis Bisnis Edisi kedua. Penerbit Rajawali Jakarta.

Umar, Haryono. 2018. The Influence of Internal Control And Competence of Human Resources on Village Fund Management and The Implications on The Quality of Village Financial Reports.International Journal of Civil Engineering and Technology (IJCIET). Volume 9, Issue 7, Juli 2018, PP.1523-1531. ISSN Print 0976-6308.ISSN Online 0976-6316.

Utaminingtyas, TH. 2019. Factors Affecting Quality of Village Financial Statement. $3^{\text {rd }}$ CEEBA International Comference on Economic, Volume 2019.

UNDP. 1997. Governance for Sustainable Human Development. UNDP Policy Paper, New York:UNDP.

Yesnia, NI. Et al.2018. Analisis Faktor Yang Mempengaruhi Akuntabilitas Pengelolaan Alokasi dana Desa (Study Kasus Pada Kecamatan Yosowilangun Kabupaten Lumajang. Jurnal Akuntansi Riset Prodi Akuntansi Fakultas Ekonomi \& Bisnis Universitas Pendidikan Indonesia. ISSN : 2086 -2563 (print). ISSN 2541 -0342 (online).

Yaya. Santosa. 2018. Village Fund Management And Factors That Affect Its Performance In Indonesia. $3^{\text {rd }}$ CAAGA Comference, Seoul 14-18 November 2018.

Zuliarti.(2012).Pengaruh Kapasitas Sumber Daya Manusia, Pemanfaatan Teknologi Informasi, Pengendalian Intern Terhadap Nilai Informasi Pelaporan Keuangan Pemda Kudus. Jurnal FE UMK. 